\title{
Accumulation of heavy metals in a constructed wetland treating road runoff
}

\author{
Laurence W. Gill a,*, Pamela Ring ${ }^{\mathrm{a}}$, Neil M.P. Higgins ${ }^{\mathrm{b}}$, Paul M. Johnston ${ }^{\mathrm{a}}$ \\ a Department of Civil Structural and Enviran mental Engineering Trinity College Dublin, Ireland \\ Dublin City Council, Ireland
}

\begin{abstract}
The long-term performance of a constructed wetland treating highway runoff has been studied with respect to heavy metal removal in a temperate, maritime Irish climate. The accumulation of heavy metals in both the sediment and the plants growing in the wetland have been quantified over a 6 year period of operation as well as the spatial distribution of the metals' deposition. Based on the measured accumulation and projected runoff loads over a 6 year period, the removal efficiencies were $7 \%(\mathrm{Cd}), 60 \%(\mathrm{Cu}), 20 \%(\mathrm{~Pb})$ and $73 \%(\mathrm{Zn})$, values which are much less than the apparent removal efficiencies for the system determined from monitoring the inlet and outlet of discrete storm events which were $95 \%(\mathrm{Cd}), 88 \%(\mathrm{Cu}), 86 \%(\mathrm{~Pb})$ and $95 \%(\mathrm{Zn})$. The study also quantified that an almost negligible mass metals had accumulated in the vegetation compared to the sediment. There was a strong correlation between the spatial accumulation of $\mathrm{Cu}, \mathrm{Pb}$ and $\mathrm{Zn}$ with most of these metals deposited at front of the wetland in the sediment. Finally, although the wetland was initially planted with Typha latifolia over one half and Phragmites australis the other half, after 6 years of operation the Phragmites had spread to colonise almost all of the wetland.
\end{abstract}

\section{Keywords}

- $\quad$ Constructed wetland;

- Highway runoff;

- Heavy metals;

- Phytoremediation

\section{Introduction}

Constructed wetlands are increasingly being installed as systems to treat highway runoff. Typical pollutants in highway runoff include hydrocarbons, nutrients, PAHs and heavy metals (Sansalone and Buchberger, 1997; Hvitved-Jacobsen et al.., 2010). The most problematic heavy met als with regards to ecological toxicity are $\mathrm{Hg}, \mathrm{Cd}, \mathrm{Pb}, \mathrm{As}, \mathrm{Cu}, \mathrm{Zn}, \mathrm{Sn}$, and $\mathrm{Cr}$ (Ali et al., 2013), although $\mathrm{Cu}$ and $\mathrm{Zn}$ are also essential trace elements. Heavy metals in road runoff tend to be associated with fine particulate matter, particularly in first flush loads (Barbosa and Hvitved-Jacobsen, 1999; Zhao et al., 2010). The streams/rivers into which typically highway runoff is diverted needs to be protected from heavy metals due to their impact on biodiversity, particularly since they are essentially non-biodegradable.

\footnotetext{
* Correspond ing author. Tel: +353 18961047 .

E-mail address: laurence.gilløtcd.ie (L.W. Gill).
}

Constructed wet lands provide the environment for a variety of different attenuation processes for treatment of highway runoff. Physical treatment occurs as a result of decreasing flow velocities in the wetland which promotes sedimentation, evaporation, adsorption, and filtration. Biological processes include decomposition, plant uptake and removal of nutrients, plus biological transformation and degradation (Kadlec and Wallace, 2009). Several full-scale trials using a variety of different constructed wetland configurations to intercept and treat road runoff have been reported, e.g. Cheng et al. (2002), Walker and Hurl (2002), Bulc and Slak (2003), Revitt et al. (2004), Adhikari et al. (2011), Headley and Tanner (2012), etc. Such studies have demonstrated that the wetlands can promote efficient flood attenuation, reduction of peak discharges and overall enhancement of the water qual ity with respect to hydrocarbons, solids and heavy metals. Removal efficiencies reported of typical heavy metals associated with road runoff (i.e. $\mathrm{Cu}, \mathrm{Zn} \mathrm{Cd}, \mathrm{Ni}$ and $\mathrm{Pb}$ ) however, have been mixed with some studies reporting almost no removal and others up to $90 \%$. Most studies investigating the relative importance of the different heavy metal removal mechanisms have found that sedimentation seemed to 


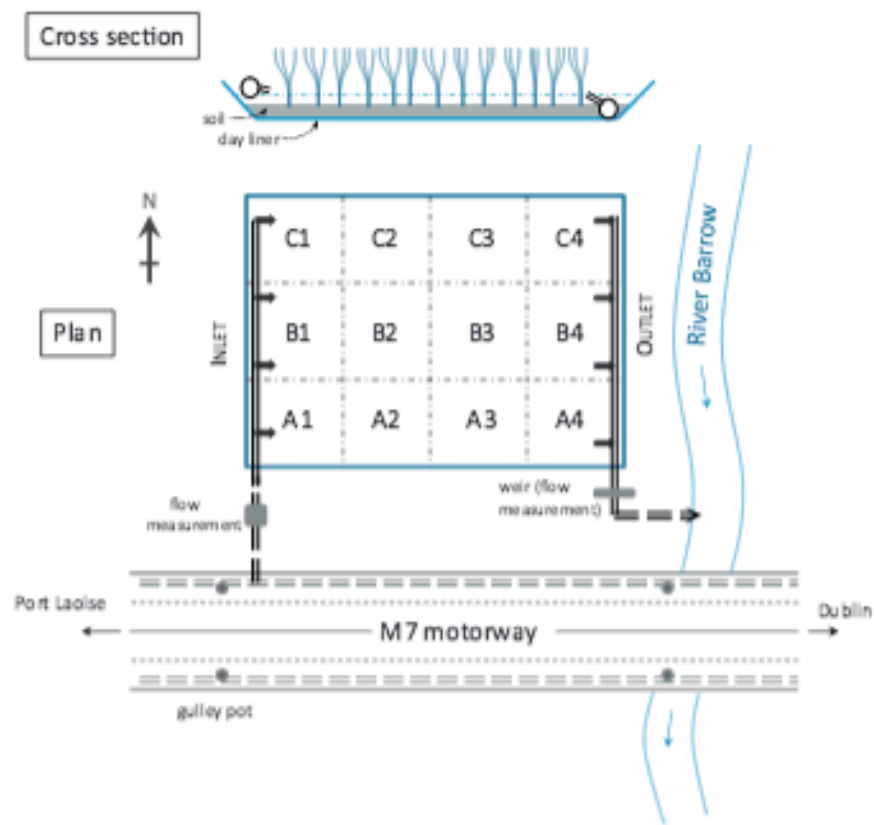

Fig. 1. Plan and cross section schematic of wetland system (with reference cell numbers).

be the dominant process compared to macrophyte uptake (Lung and Light, 1996; Mays and Edwards, 2001; Walker and Hurl, 2002). More research is still needed however, to better understand the complex interactions between contaminants, soil, plant roots, and microorganisms in the rhizosphere (Williams, 2002; Vangronsveld et al., 2009).

The construction of motorways in Ireland intensified in the last decade with traffic numbers on many roads now exceeding the 30,000 vehicles per day threshold for implication of mitigation methods as set down in Irish and UK guidance (NRA, 2008). The EU Water Framework Directive legislation is also applying pressure for the control of discharges to any receiving water whether ground or surface. Hence, the use of const ructed wetlands as a possible mitigation method to treat highway runoff in Ireland was tested with the first wetland established as a pilot trial in 2005. This wetland was intensively researched for the first year and then has been periodically checked over the subsequent 6 years to present.

\section{Materials and methods}

\subsection{Constructed wetland experimental site}

The constructed wetland was built adjacent to a new motorway linking the towns of Kildare and Portlaiose in the east of Irel and. The planareadimensions of the base were $12.7 \mathrm{~m}$ wide by $18.2 \mathrm{~m}$ length with a cross sectional slope of $1 \%$. The depth of the wetland was no greater than $0.4 \mathrm{~m}$ at any point. The runoffdrainage area of highway for the wetland was a $980 \mathrm{~m}$ straight length of hot rolled asphalt carriageway (total width $11.6 \mathrm{~m}$ ) with a standard kerb and gulley construction, the surface runoff discharging into a piped drainage system via on-line gul ly traps installed at $20 \mathrm{~m}$ intervals. The runoff entered the wetl and via four equally spaced $100 \mathrm{~mm}$ diameter pipe inlets across the inlet width to ensure even flow distribution (see Fig. 1). The outlet pipes at the same spacings had adjustable Tpieces as weirs to control the water level within the wetland (at approximately $0.3 \mathrm{~m}$ depth). A compacted clay base was laid to produce a relatively impermeable layer $\left(K<1 \times 10^{-9} \mathrm{~m} / \mathrm{s}\right)$ with a nominal $100 \mathrm{~mm}$ layer of local topsoil was added on top. The wetland first received flows in December 2004 and vegetation was planted on 5 th May 2005. The north half of the wetland was planted with 500 Phragmites australis and the south half with 500 Typha latifolia - approximately 4 plants $/ \mathrm{m}^{2}$. Since opening the motorway has had an average traffic count of just over 30,000 vehicles per day over the 6 year period (with $10.5 \%$ on average as HGV) which has been slowly increasing.

\subsection{Storm event sampling and analysis}

The site was installed with an ISCO $6740.1 \mathrm{~mm}$ tipping bucket rain gauge and ISCO 750 area velocity flow module to measure the flow into the wetland. A V-notch weir system with an ISCO 730 bubble module to measure the depth was installed at the outflow and a relationship between depth and flow over the $\mathrm{V}$ notch was established. These devices were connected to two ISCO 6712 automatic samplers which took sequential $300 \mathrm{ml}$ samples of the runoff and effluent on a flow based criteria. Between summer and autumn 2005 six major storm events were captured and fully sampled.

Storm runoff samples were analysed for total suspended solids as well as priority heavy metal pollutants $(\mathrm{Cd}, \mathrm{Cu}, \mathrm{Pb}$ and $\mathrm{Zn}$ ) commonly found in urban runoff (Eriksson et al., 2007). The water qual ity analysis was carried out in the laboratory using acid digestion followed by analysis with a Varian Liberty AX sequential ICP-AES machine (see Supplementary Information for details). For 5 out of the 6 storms the storm runoff samples for heavy metals were also fractionated into their particulate and dissolved forms by filtering the sample through $0.45 \mu \mathrm{m}$ filter paper. The discrete sample results were converted to EMC values using the mid-point volume method (Charbeneau and Barrett, 1998).

After this intensive period flow monitoring in 2006, instrumentation was removed (except the rain gauge) and the site periodically visited over the next 6 years where small adjustments were made to ensure the inlet and outlet pipes were level (using a Trimble 4700 GPS system).

\subsection{Sampling and analysis of sediment and vegetation}

After 6 years of operation the amount of heavy metals and suspended solids that had accumulated in the wetland were calculated by sampling sediment and vegetation in the summer of 2011. The wetland was divided into 12 cells of equal area (each $19.3 \mathrm{~m}^{2}$ ) as referenced in Fig. 1. Two samples of sediment were taken from each cell (total of 24 sediments samples) using a tube augur. Samples of the fresh topsoil that was used to fill the wetland during construction were also analysed to determine the initial concentration of heavy metals in the wetland. Each sediment sample was then analysed for suspended solids concentration and heavy metal $(\mathrm{Cd}, \mathrm{Cr}$. $\mathrm{Cu}, \mathrm{Ni}, \mathrm{Pb}$ and $\mathrm{Zn}$ ) concentration in the laboratory using acid digestion to extract the metals followed by ICP-AES analysis. For each sediment sample the depth of sediment to the clay liner was measured and the density of the sediment also calculated. The $\mathrm{pH}$ of the water and redox of the water as well as in the sediment was also measured in each cell at the time of sampling in situ with a field probe (YSI 556MPS).

Two complete plants (stem and roots) were carefully dug up and taken from eachcell (total of 24 plant samples). In addition, the number of plants in a $1 \mathrm{~m}^{2}$ quadrat within each cell was counted to give a representative density from which the total number in each cell was calculated. By the summer 2011 the P. australis had colonised all but one square (A4) of the wetland with the T. latifolia only still growing in a small area near the outlet zone. The plant samples were taken immediately to the laboratory for analysis 

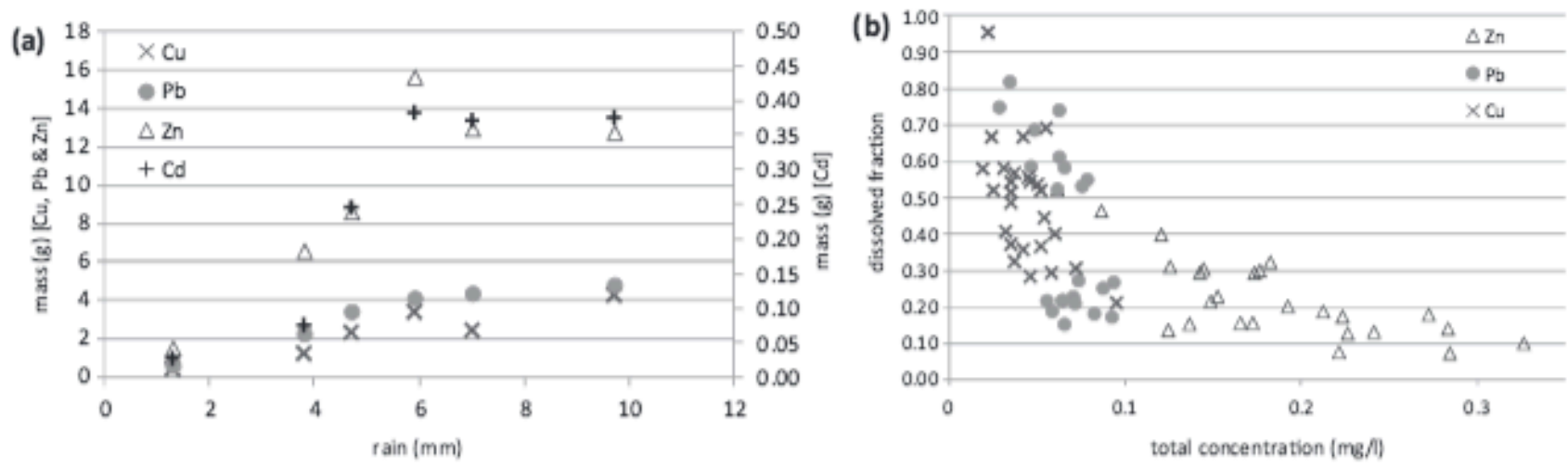

Fig. 2. Heavy metals highway runoff into wetland: (a) relationship to storm rainfall and (b) dissolved fraction.

where they were thoroughly washed in distilled water to remove any clay/sediment before being separated into three different parts - roots, stem and leaf - and cut into $2 \mathrm{~cm}$ segment samples. They were then each weighed and recorded and placed in an oven at $105^{\circ} \mathrm{C}$ to establish the dry mass. They were then ground down and acid digested as per the method detailed above for the sediment samples before being analysed using ICP-AES.

\section{Results}

\subsection{Storm runoff and wetland treatment performance}

The hydrological characteristics of the 6 storm events intensively monitored during 2005 showed that the constructed wetland performed well hydraulically, buffering the inflow to the system from the highway and substantially reducing the peak flow by over $90 \%$ (see Supplemental Information). The nominal hydraulic retention times (HRT) for the wetland during these periods varied from between just $21 \mathrm{~min}$ to $8.7 \mathrm{~h}$ (not far off the recommended design criteria for 1 in 10 year storm design event (Schutes et al., 1999)). However, much of the runoff was detained by the wetland for a number of days and then was discharged by subsequent rainfall events. The storms produced representative events for the temperate maritime climate in Ireland with antecedent dry days for the storms varying from 0 to 4 days - such relatively low intensity events are very common with over $90 \%$ of storms over the 6 year monit oring period following periods of rain at least $48 \mathrm{~h}$ before hand.

A summary of the event mean concentrations for both total and dissolved fraction is given in the Supplemental Information. The individual flow weighted samples revealed a high correlation between all metal species and TSS in the influent as well as metals removed. The relationship between the heavy metal loads into the wetland and against rainfall per storm in Fig. $2 a$ shows that the higher the volume of rainfall, the more metals delivered to the wetland up to $7 \mathrm{~mm}$ at which point there seems to be a tapering off indicating that most wash off had occurred by that point. Interestingly, however there was no discernible relationship between highway runoff and rainfall intensity, which may be due to the relatively low range of rainfall intensities experienced and short antecedent dry conditions.

The analysis of the flow based influent samples for their dissolved fractions of $\mathrm{Cu}, \mathrm{Pb}$ and $\mathrm{Zn}$ (Fig. $2 \mathrm{~b}$ ) indicated an inverse relationship between concentration and dissolved fraction (i.e. more of the metals were associated with the particulate fraction at higher concentrations). The $\mathrm{Zn}$ load in the highway runoff was more associated with particulate form, whereas $\mathrm{Cu}$ and $\mathrm{Pb}$ demonstrated a broader spectrum up to much higher dissolved fractions. Interestingly, $\mathrm{Pb}$ in the runoff seemed to be grouped into two distinct sets, one with a high particulate fraction, the other with a high dissolved fraction, perhaps indicating two different mechanisms (or sources) of deposition onto the highway.

\subsection{Heavy metal accumulation in sediment and vegetation}

\subsubsection{Sediment}

The amount of heavy metals in the wetland after 6 years of operation is shown in Fig. 3. Cu, $\mathrm{Pb}$ and $\mathrm{Zn}$ show much higher deposition in the sediment at front of the system (i.e. cells 1 ) with a very high correlation between where they accumulated. Conversely Cd showed little relationship to most of the other metals. Statistical analysis on the location of accumulation showed the highest levels at the front of wetland (with cell A1 accounting on average for $26.4 \%$ of metal accumul at ion) with levels diminishing with distance through the wet land as well as evidence of channelling through the A cells and a hydraulic dead-zone in the area of cells B3 and $\mathrm{C} 3$. The concentrations of the heavy metals in the sediment samples were much higher compared to the topsoil that was originally used to fill to wetland indicating significant accumulation over 6 years of operation. In general the concentrations were highest for $\mathrm{Zn}$ (reflecting it being highest in the highway runoff) with mean concentrations in the sediment as follows: $0.91(\mathrm{Cd}), 17.0(\mathrm{Cr}), 62.1(\mathrm{Cu}), 20.1(\mathrm{Ni})$, $37.5(\mathrm{~Pb})$ and $269.3(\mathrm{Zn}) \mathrm{mg} / \mathrm{kg}$.

\subsubsection{Vegetation}

The spatial pattern of heavy metals in the vegetation (net roots, leaves and stems) is shown in Fig. 3. The fraction of the overall mass of heavy met als accumulated in the wetland within the vegetation was very small: $0.73 \%(\mathrm{Cd}), 1.35 \%(\mathrm{Cr}), 2.07 \%(\mathrm{Cu}), 1.23 \%(\mathrm{Ni})$, $0.55 \%(\mathrm{~Pb})$ and $0.61 \%(\mathrm{Zn})$. The concentrations of metals within the leaf, stem and root parts of the plant samples taken from each cell (see Supplemental Information) revealed that almost no $\mathrm{Cd}$ was being transported to either the leaves or stems of the plants. $\mathrm{Cu}$ revealed the highest concentrations in the leaves compared with the other heavy metals, although only elevated in cells A2 and A3 al though $\mathrm{Zn}$ showed the highest concentrations most consistently across all the cells in the leaves and stems. Levels for $\mathrm{Cr}, \mathrm{Ni}$ and $\mathrm{Pb}$ are broadly similar between the leaves and stem concentrations. The concentrations of heavy metals found in the roots of the plants were 4-5 times higher on average compared to the stem and leaf results for all metals with the noticeable exception of $\mathrm{Pb}$ (which was more than 20 times higher). Cu and then $\mathrm{Zn}$ revealed the highest translocation factors (Padmavathiamma and $\mathrm{Li}, 2007$ ) which can be attributed to them being essential trace metals. In contrast 
to the above ground samples concentrations of $\mathrm{Cd}$ were measured in all of the root samples. However, in general the concentrations of the different heavy metals in the leaves, stems and roots were insignificant when compared with the sediment levels. Note, all results represent analysis on $P$. australis with the exception of the $T$. latifolia located in cell A4 which revealed metal concentrations within the same spectrum as the other cells in similar positions in the wetland. A cross correlation between the different metals in the plants showed a reasonable correlation between most metals

\section{Cd sediment}

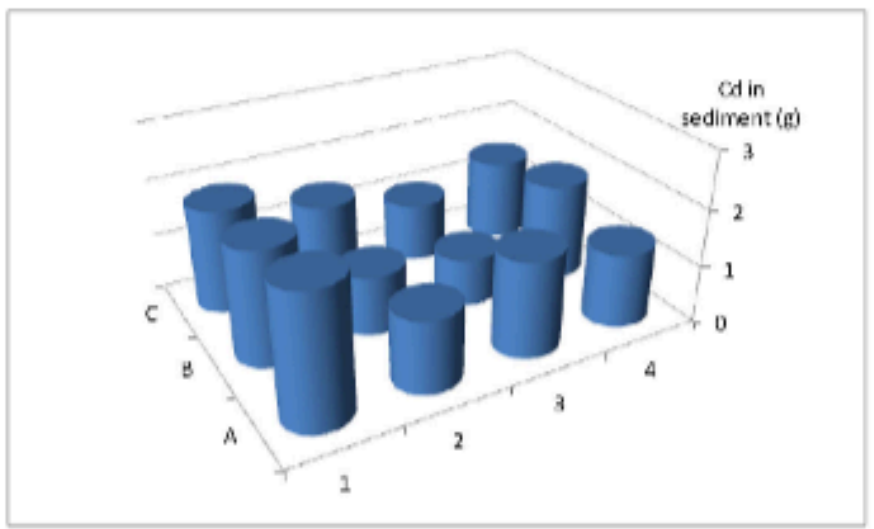

$\mathrm{Cr}$ sediment

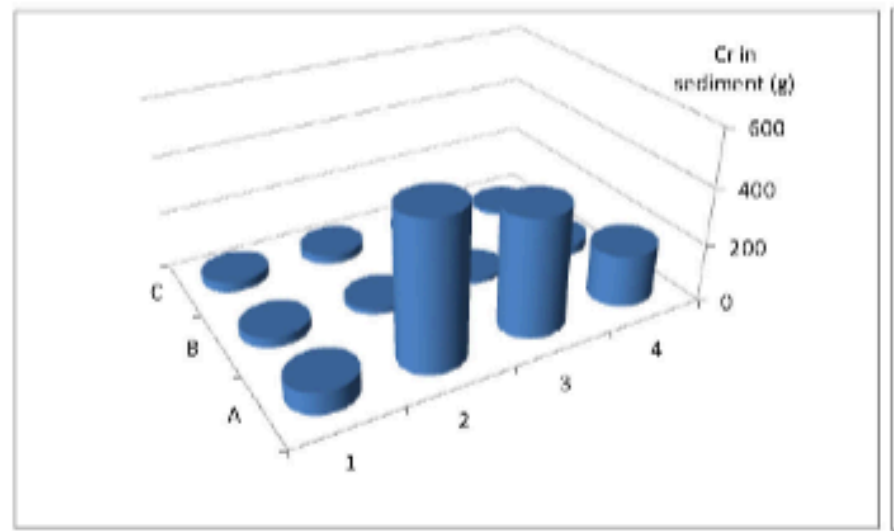

\section{$\mathrm{Cu}$ sediment}

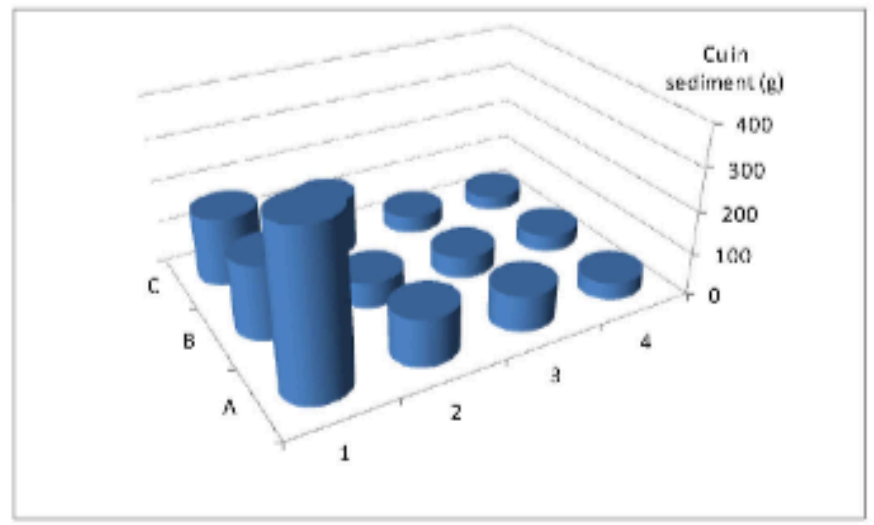

(with the noticeable exception of $\mathrm{Cu}$ ) but no significant correlations were found between sediment concentration and concentration in the plants.

\subsection{Comparison between heavy metal accumulation and predicted performance}

An analysis of the predicted runoff loads into the wetland using the data collected from the intensely monitored storm events in 
Table 1

Mass of metals accumulated in CW and total removed vs. pred icted in runoff (g).

\begin{tabular}{|c|c|c|c|c|c|c|}
\hline & $\mathrm{Cd}$ & $\mathrm{Cr}$ & $\mathrm{Cu}$ & $\mathrm{Ni}$ & $\mathrm{Pb}$ & $\mathrm{Zn}$ \\
\hline $\mathrm{A} 1$ & 2.33 & 76.8 & 382.5 & 65.3 & 202.5 & 1530.8 \\
\hline $\mathrm{A} 2$ & 1.28 & 28.7 & 120.2 & 32.4 & 71.6 & 514.0 \\
\hline A3 & 1.72 & 22.9 & 91.8 & 34.9 & 60.9 & 421.6 \\
\hline A4 & 1.31 & 14.4 & 41.2 & 28.3 & 28.3 & 182.8 \\
\hline B1 & 2.04 & 37.3 & 178.5 & 50.4 & 92.6 & 658.5 \\
\hline B2 & 1.04 & 20.2 & 61.4 & 22.4 & 37.7 & 271.4 \\
\hline B3 & 0.85 & 16.5 & 52.9 & 19.1 & 32.2 & 220.9 \\
\hline B4 & 1.72 & 38.6 & 40.9 & 44.4 & 33.7 & 215.5 \\
\hline $\mathrm{Cl}$ & 1.85 & 35.1 & 165.4 & 44.2 & 94.5 & 697.6 \\
\hline $\mathrm{C}_{2}$ & 1.46 & 32.6 & 136.1 & 34.9 & 77.1 & 597.1 \\
\hline $\mathrm{C} 3$ & 1.05 & 15.7 & 42.5 & 22.0 & 30.5 & 202.2 \\
\hline $\mathrm{CA}_{4}$ & 1.44 & 13.3 & 35.5 & 22.0 & 26.9 & 195.6 \\
\hline Total in wetland (g) & 18.09 & 352.1 & 1348.8 & 420.4 & 788.6 & 5707.9 \\
\hline Total removed (g) & 10.55 & 179.0 & 1043.8 & 164.3 & 494.0 & 4593.7 \\
\hline Predicted (g) & 142.3 & - & 1731.8 & - & 2492.8 & 6294.4 \\
\hline
\end{tabular}

inlet and outlet of discrete storm events which were $95 \%(\mathrm{Cd}), 88 \%$ $(\mathrm{Cu}), 86 \%(\mathrm{~Pb})$ and $95 \%(\mathrm{Zn})$. In particular, much less $\mathrm{Cd}$ and $\mathrm{Pb}$ appeared to accumulate than would have been predicted from the early monitoring results, indicating either a reduction in treatment efficiency over time or possible remobilisation of these metals from the sediments. Interestingly a review of 17 constructed wetlands treating urban runoff in Kadlec and Wallace (2009) showed on average higher removal efficiencies for $\mathrm{Cd}$ and $\mathrm{Pb}$ (71\% and 74\%) than for $\mathrm{Cu}$ and $\mathrm{Zn}(49 \%$ and $60 \%)$. Other studies have reported varying removal efficiencies: e.g. Revitt et al. (2004) reported median $\mathrm{Cu}$ and $\mathrm{Pb}$ removal efficiencies of 40-75\% across highway runoff storm events in the UK: Walker and Hurl (2002) found 57\% ( $\mathrm{Zn}), 71 \%$ $(\mathrm{Pb})$ and $48 \%(\mathrm{Cu})$ removal efficiencies in Australia; and Terzakis et al. (2008) showed removal efficiencies of $23 \%(\mathrm{Cu}), 33 \%(\mathrm{Ni}), 61 \%$ $(\mathrm{Pb})$ and $59 \%(\mathrm{Zn})$ in Crete. Most of these studies, however, were based on comparing inlet and outlet samples during single peak storm events which, as discussed above, is debatable as to whet her such a methodology provides an accurate indication of overall long term removal efficiency for such vegetated systems. The concentrations of metals for both total and dissolved fractions in the road runoff storm profiles broadly matched other sites being monitored in Ireland (Bruen et al., 2006) as well as el sewhere (Barbosa and Hvitved-Jacobsen, 1999; Terzakis et al., 2008; Borne et al., 2013) with the highest overall metal concentrations in the road runoff associated with the particulate form and a trend of lower dissolved fractions with higher flows.

Contemporary thoughts provide different conclusions as to the ability of plants to efficiently decontaminate heavy metals (Adams et al., 2012; Rai, 2012). The fraction of overall load in the living vegetation during the summer of 2011 was $0.73 \%(\mathrm{Cd}), 1.35 \%(\mathrm{Cr})$, $2.07 \%(\mathrm{Cu}), 1.23 \%(\mathrm{Ni}), 0.55 \%(\mathrm{~Pb})$ and $0.61 \%(\mathrm{Zn})$ and therefore negligible compared to accumulation in the sediment which concurs with several other studies on road runoff (Mays and Edwards, 2001; Walker and Hurl, 2002; Pilon-Smits, 2005; Lee and Scholz, 2007). In addition, where studies have found any accumulation of heavy metals in plants, the consensus seems to be that little accumulation occurs in the above ground matter (stems and leaves) with most accumulation in the roots (Cheng et al., 2002; Ben Salem et al.,2014). The percent age of overall annual metal load contained in the leaves and stem varied from $0.1 \%$ for $\mathrm{Pb}$ up to a maximum of only $1.2 \%$ for $\mathrm{Cu}$. The comparison of the different parts of the plant clearly showed that the metal concentrations are much higher in the roots than above ground shoots and leaves by an average factor of $4.8(\mathrm{Cr}), 6.3(\mathrm{Cu}), 6.6(\mathrm{Ni}), 21.0(\mathrm{~Pb})$ and $5.0(\mathrm{Zn})$, again similar to other studies (Cheng et al., 2002; Di Luca et al., 2011). However, the total mass contained in the roots compared to the total mass in above ground vegetation revealed closer average factors of $1.56(\mathrm{Cr}), 0.84(\mathrm{Cu}), 1.89(\mathrm{Ni}), 7.14(\mathrm{~Pb})$ and $1.64(\mathrm{Zn})$. There was no relationship however, between plant numbers and the heavy metal concentration in the roots. Equally, there was no relationship between the number of plants in each cell and the sediment accumulated (depth) as might have been expected $(R=-0.195)$. Finally, the somewhat limited comparison between $P$. australis and $T$. latifolia showed broadly similar concentrations in leaf, stems and roots for all metals (given the position of the cell A4), matching the findings of Arroyo et al. (2013). Typha had clearly struggled compared to the Phragmites that had colonised al most the entire wetland after 6 years which has been shown to act as an invasive species in many places across the world with competitive advantages due to high rates of primary productivity (Brisson et al., 2010).

The pattern of accumulation across the wetland in general revealed lower concentrations of metals in the sediment with length through the wetland (inlet to outlet) which corresponds with other studies (Wal ker and Hurl, 2002; Di Luca et al., 2011). This could indicate that sedimentation is the primary initial removal mechanism. $\mathrm{Cu}, \mathrm{Pb}$ and $\mathrm{Zn}$ showed much higher deposition at front of system (i.e. cells 1) with a very high correlation between them. $\mathrm{Zn}$ also revealed higher deposition further into wetland (despite it being in the mostparticulate form in runoff) which may be evidence of some remobilisation process at higher flow rates or its release in a dissolved form after wetland processes in the sediment. Despite Cuin the road run off having a higher dissolved fraction compared to $\mathrm{Zn}$ and $\mathrm{Pb}$ (Fig. 2b) still most of its load in the sediment had accumulated at the front of system, indicating other removal mechanisms than just sedimentation. Generally reducing conditions were found in the sediment in this wet land study (down to $-160 \mathrm{mV}$ ) with aerobic conditions in the surface water as found in other studies such as Faulwetter et al. (2009). These reduced conditions would promote anaerobic processes such as sulphate reduction, providing the sulphide which could act to precipitate the divalent metal cations.

One explanation for the more consistent apparent accumulation of $\mathrm{Cu}$ and $\mathrm{Zn}$ over time compared to $\mathrm{Cd}$ and $\mathrm{Pb}$ might be that $\mathrm{Cu}$ and $\mathrm{Zn}$ would have more interaction with the vegetation being essential trace metals. The numbers (and size) of the plants has burgeoned over the years with $>24,000$ full size reeds (most between 2.5 and $3 \mathrm{~m}$ tall) growing in summer 2011. Although the above ground plant matter was shown to contain only a relatively small fraction of metals, the annual cycle of uptake int o the growing plants with subsequent die back to produce organic sediment may cumulatively over several years have a more significant impact.

\section{Conclusions}

Over a 6 year period the wetland has removed a considerable amount of the heavy metals associated with road runoff that otherwise would have discharged directly to the river. Based on the measured accumulation and projected runoff loads, the long term heavy metal removal efficiencies over a 6 year period were considerably lower than the apparent removal efficiencies determined from the sampling of discrete st orm events which also highlighted potentially different removal/remobilisation processes between Cd and $\mathrm{Pb}$ as opposed to $\mathrm{Cu}$ and $\mathrm{Zn}$ in such awetland environment. The study al so quantified that an almost negligible mass of metals had accumulated in the vegetation compared to the sediment.

\section{Acknowledgments}

The Environmental Protection Agency (EPA) and National Roads Authority (NRA) funded the construction of the wetland and initial 
storm event sampling. Thanks also to David Morgan for guidance with the analytical work in the laboratory.

\section{Appendix A. Supplementary data}

Supplementary data associated with this article can be found, in the online version, at http://dx,doi.org/10.1016/j.ecoleng. 2014.03.056.

\section{References}

Adams, A., Raman, A. Hodgkins, D, 2012. How do the plants used in phytoremediation in constructed wetlands, a sustainable remediation strategy. perform in heavy-metal-cont aminated mine sites? Water Environ. L 1-13.

Adhikari, A.R. Acharya, K. Shanahan, S.E. Zhou, X. 2011. Removal of nutrients and metals by constructed and naturally created wetlands in the Las Vegas Valley. Nevada. J. Monit. Assess. 180, 97-113.

Ali. H_. Khan. E. Sajad, M.A.2013. Phytoremediation of heavy metals - concepts and applications Chemosphere 91, 869-881.

Arroyo, P.. Ansola, G. Sáenz de Miera, LE., 2013. Effects of substrate, vegetation and flow on arsenic and zinc removal efficiency and microbiald iversity in constructed wetlands. Ecol. Eng. 51,91-103.

Barbosa. A.E. Hvitved-Jacobsen, T. 1999. Highway runoff and potential for removal of heavy metals in an infiltration pond in Portugal. Sci. Total Environ.235 (1-3), $151-159$.

Ben Salem, Z. Laffray, X., Ashoour, A. Ayadi, H., Aleya, L. 2014. Metal accumulation and distribution in the organs of Reeds and Cattails in a constructed treatment wetland (Etueffont, France). Ecol. Eng. 64, 1-17.

Borne, K.E. Fassman, E.A. Tanner, C.C. 2013. Foating treatment wetland retrofit to improve stormwater pond performance for suspended solids, copper and zinc. Ecol. Eng. 54, 173-182.

Brisson, J de Blois, S. Lavoie, C 2010 . Roadside as invasion pathway for common reed ( Phragmites atustral is). Invasive Plant Sci. Manag. 3 (4), 506-514.

Bruen, M. Johnston, P. Kelly Quinn, M. Destsa, M. Higgins, N. Bradley, C. Bums, S. 2006. Impact Assessment of Highway Drainage on Surface Water Quality. Environmental Protection Agency, Wexford, Ireland.

Bulc. T. Slak A.S. 2003. Performance of a constructed wetland for highway runoff treatment. Water Sci. Technol. 48 (2), 315-322.

Charbeneau, R.J. Barrett, M.E., 1998. Evaluation of methods for estimatingstormwater pollutant loads. Water Environ. Res. 70, 1295-1302.

Cheng S. Grosse, W. Karrenbrock. F. Thoennessen, M. 2002. Efficiency of constructed wetlands in decontamination of water polluted by heavy metals. Ecol. Eng. 18, 317-325.

Di Luca, GA., Maine, M.A, Mufarrege, M.M., Hadad, H.R., Sánchez, G.C., Bonetto, C.A. 2011. Metal retention and distribution in the sediment of a constructed wetland for industrial wastewater treatment. Ecol. Eng. 37, 1267-1275.

Eriksson. E. Baun. A. Scholes, L. Ledin. A.Ahlman, S. Revitt, M. et al. 2007. Selected stormwater priority pollutants - a European perspective. Sci. Tot. Environ. 383 (1-3), 41-51.
Faulwetter, J.L. Gagnon, V., Sundberg, C. Chazarenc, F, Burr, M.D., Brisson, JCamper, A.K., Stein, O.R., 2009. Microbial processes influencing performance of treatment wetlands: a review. Ecol. Eng. 35 (6). 987-1004

Headley, T.R. Tanner, C.C. 2012. Constructed wetlands with floating emergent macrophytes an innovative stormwater treatment technology. Crit. Rev. Environ. Sci. Technol. 42 (21), 2261-2310.

Hvitved-Jacobsen, T., Vollertsen, J. Nielsen, A.H. 2010. Urban and Highway Stormwater Pollution: Concepts and Engineering. CRC Press, Boca Raton, FL.

Kadlec, R.H Wallace, S.2009. Treatment Wetlands, 2nd ed. CRC Press, Boca Raton. $\mathrm{FL}$.

Lee, B.-H. Scholz, M. 2007. What is the role of Phragmites australis in experimental constructed wetland filters treating urban runoff? Ecol. Eng. 29, 87-95.

Lung. W-S. Light, RN 1996. Modelling copper removal in wetland ecosystems. Ecol. Model. 93, 89-100.

Mays, P.A. Edwards, G.S. 2001. Comparison of heavy metal accumulation in a natural wetland and constructed wetlands receiving acid mine drainage. Ecol. Eng $16,487-500$

National Roads Authority, 2008. Guidelines on Procedures for Assessment and Treatment of Geology. Hydrology and Hydrogeology for National Road Schemes. National Roads Authority. Dublin, Ireland.

Padmavathiamma, P.K., Li, LY, 2007. Phytoremediation technology: hyperaccumulation metals in plants. Water Air Soil Pollut. 184, 105-126.

Pilon-Smits, E. 2005. Phyto remediation. Annu. Rev, Plant Biol. 56, 15-39,

Rai, P.K., 2012. An eco-sustainable green approach for heavy metals management: two case studies of developing industrial region. Environ.Monit. Assess. 184 (1) $421-448$.

Revitt, D.M_Schutes, R_B. Jones, R.H_. Forshaw, M. Winter, B. 2004. The performances of vegetative treatment systems for highway runoff during dry and wet conditions. Sci. Total Environ. 335, 261-270.

Sansalone. J. Buchberger. S.G. 1997. Characterization of solid and metal element distributions in urban highway stormwater. Water Sci. Technol. 36 (8-9) $155-160$.

Schutes, R.B.E, Revitt. D.M_ Lagerberg. LM_. Barraud. V.C.E. 1999. The design of vegetative constructed wetlands for the treatment of highway runoff. Sci. Total Environ. 235 (1-3). 189-197.

Terzakis, S. Fountoulakis, MS, Georgaki, I Albantakis, D. Sabathianakis, L Karathanasis, A.D_. Kalogerakis, N. Manios, T. 2008. Constructed wetlandstreating highway runoff in the central Mediterranean region. Chemosphere 72 . 141-149.

Vangronsveld.J_Herzig. R_Weyens, N..Boulet.J_Adriaensen, K. Ruttens, A. Thewys, T. Vassilev, A. Meers, E.Nehnevajova, E. Vander Lelie, D. Mench. M. 2009. Phy. toremediation of contaminated soils and groundwater: lessons from the field. Environ. Sci. Pollut. Res. 16, 765-794.

Walker, D J. Hurl, S. 2002. The reduction of heavy metals in a stormwater wetland. Ecol Eng. 18, 407-414

Williams. J B 2002. Phytoremediation in wetland ecosystems progess, problems, and potential. Crit. Rev. Plant Sci. 21, 607-635.

Zhao, H. Li X. Wang. X. Tian, D. 2010. Grain size distribution of road-deposited sediment and its contribution to heavy metal pollution in urbanrunoff in Beijing China.J. Hazard. Mater. 183, 203-210 